\title{
Identification of Competencies for Malaysian Occupational Safety and Health Professionals
}

\author{
Rabaayah DAUD¹, Maimunah ISMAIL ${ }^{2 *}$ and Zoharah OMAR ${ }^{2}$ \\ ${ }^{1}$ Ministry of Human Resources, Putrajaya, Malaysia \\ ${ }^{2}$ Department of Professional Development and Continuing Education, Faculty of Educational Studies, \\ Universiti Putra Malaysia, 43400 Serdang, Malaysia
}

Received June 23, 2009 and accepted February 1, 2010

\begin{abstract}
Competencies of occupational safety and health (OSH) professionals have become a concern due to the significance of safety management in the field of safety engineering. The purpose of this article is to identify competencies needed by OSH professionals. These competencies are required by professionals in administrating and enforcing legislations related to OSH in Malaysia. This study used Delphi technique in three rounds of data collection. The benefits of this research approach are the use of experts in gaining opinions without time and geographical restraints. The results show 25 generic competencies with combinations of cognitive, interpersonal and intrapersonal competencies and 33 functional or specific competencies including knowledge and skills needed by OSH professionals. Both generic and functional competencies are also divided into threshold and differentiating competencies that would be used to differentiate average and excellent performance of OSH professionals.
\end{abstract}

Key words: Competencies, Delphi technique, Malaysia, Occupational safety and health

\section{Introduction}

Occupational safety and health (OSH) is an important profession that ensures the health and safety aspects in various workplaces ${ }^{1-3)}$. WHO/ILO ${ }^{4)}$ reports that there is growing acceptance throughout the world that accidents and ill-health at work do impact not only on the lives of individual workers, their families and their potential for future work, but also the productivity of their organizations. It has also been reported that about 2.2 million work-related deaths occur annually as a result of work place accidents and occupational diseases ${ }^{5,6)}$ and these cost the nations worldwide, including Malaysia, billions of dollars in workers' compensation, medical costs, and work efficiency.

Nonetheless, despite the pressing need for having competent OSH professionals, there is a general concern for identifying the necessary competencies required in the safety and health profession for effective performance of the $\mathrm{OSH}$ related functions ${ }^{7)}$. In Malaysia, the

*To whom correspondence should be addressed.

E-mail: mismail@educ.upm.edu.my law requires organizations to hire OSH professionals in their organizations ${ }^{8}$. The Department of Occupational, Safety and Health (DOSH), Malaysia reported that there were 25,457 OSH practitioners including Safety and Health Officers (SHOs), noise competent persons, chemical health risk assessors and occupational health doctors in 2007. Until May 2009, the department had 677 enforcement officers divided among one Head Office and 13 State Offices. As the number of workplace increases, Malaysia still needs another 20,000 OSH professionals $^{9}$ ). In terms of SHOs, it is expected that the Ninth Malaysian Plan (9MP) will require an additional $1,500 \mathrm{SHOs}^{10)}$. The 9MP (2006 to 2010) ${ }^{11)}$ is the current 5-yr phase of the country's long-term development plans which started in 1966. The long-term plans including 9MP consist of policies towards materializing the national vision of attaining developed nation status by the year 2020. One of the policies is to meet the increasing demand for trained and experienced human resources at managerial, supervisory and technical levels, and one of focus groups is in the occupational and health profession located in the various public service and industrial organizations. To achieve this end, there- 
fore, competencies of the professionals in the profession need to be ascertained to facilitate the various human resource development and management initiatives.

Master Builders Association of Malaysia (MBAM) urges the relevant authority to consider reviewing the training fees and duration because of the need to produce more SHOs to meet the demand. Although there are urgent needs for competent OSH professionals, there is no specific competency framework developed that would be used as a guide for OSH professionals in Malaysia.

At the international level, there is one competency model developed for OSH professionals ${ }^{12)}$ which consists of differentiating competencies and threshold competencies. Specifically the model contains 11 differentiating and 3 threshold competencies for the safety profession, 9 differentiating and 3 threshold competencies for industrial hygiene and 8 differentiating and 4 threshold competencies for the environmental profession. However, the extent to which these competencies are applicable to Malaysian OSH professionals has yet to be tested empirically. Most Malaysian studies on OSH professionals were related to training need assessment and training curriculum for the professionals ${ }^{13}, 14$ ). Based on the above premise, this article reports results of a study aimed to identify the necessary competencies for OSH professionals in terms of threshold and differentiating competencies using the Delphi technique. This article first discusses competency models used as the underlying theories in the study. Second, the Delphi technique and the rationale for its application are briefly explained. Third, the procedures undertaken that include processes involved in the use of the Delphi technique, population, sampling and instrument, followed by the study results, discussion and conclusion. The article ends with recommendations for practice and research in the $\mathrm{OSH}$ profession.

\section{Competency models for OSH professionals}

Competency is defined as an underlying characteristic of a person, in that it may be a motive, trait, skill, aspect of one's self-image or social role, or a body of knowledge which he or she uses, which is causally related to the achievement of effective or better work performances ${ }^{15)}$. A later definition refers to competency as an underlying characteristic of an individual that is causally related to criterion-referenced effective performance in a job or situation ${ }^{16)}$. The definitions indicate that competencies are underlying characteristics of people pointing towards the ways of behaving and thinking across situations.

Competencies of OSH professionals have become a recent concern because of the demands to meet chal- lenges confronting the profession. It is argued that during this millennium not only has the OSH profession grown in size and complexity; it has also expanded its emphasis not only on safety engineering but also on safety management. This implies that OSH managers need to identify the specific roles and behaviours needed to manage, maintain and develop employees as well as to accomplish the goals of reducing injuries in the workplace $\left.{ }^{7}, 17-19\right)$. Three models have been used as the underlying competency theories in this study and the section that follows briefly explains each of these theories.

\section{Iceberg model of competency}

The Iceberg Model of Competency ${ }^{16)}$ conceptualizes five types of competency characteristics: 1) motive; 2) traits; 3) social role and self-concept; 4) knowledge; and 5) skills. Knowledge and skill competencies tend to be visible, measurable and can be developed through training. Meanwhile, social role, self concept, trait, and motive competencies are more hidden and they represent a person's central personality. Degrees of difficulties in execution, types and examples of competencies are summarized in Fig. 1. The competencies are further categorized into two groups, namely, threshold and differentiating according to prediction of the job performance criterion. The threshold competencies are the essential characteristics (knowledge, skills and ability) needed for everyone to be minimally effective in a job. However, these competencies do not distinguish superior from average performers. Meanwhile, differentiating competencies are the characteristics or factors such as motive, trait and/or pattern of behavior that distinguish superior from average performers.

\section{Environmental, Health and Safety (EHS) competency model}

The second model used for investigating competencies in this study was based on competencies needed for the environmental, health and safety (EHS) profession ${ }^{12)}$ that specifically consist of roles, functions and competencies of the safety professionals, industrial hygiene professionals and environmental professionals. These competencies distinguish superior performance among EHS professionals as well as their ability to deliver business values to the organization. This shows that safety and health jobs are complex. When compared to other technical occupations, EHS professionals must master two to three times as many competencies compared to the other technical professionals in order for them to perform better.

It is further stated that success in the EHS profession requires not only mastery of the technical expertise but 


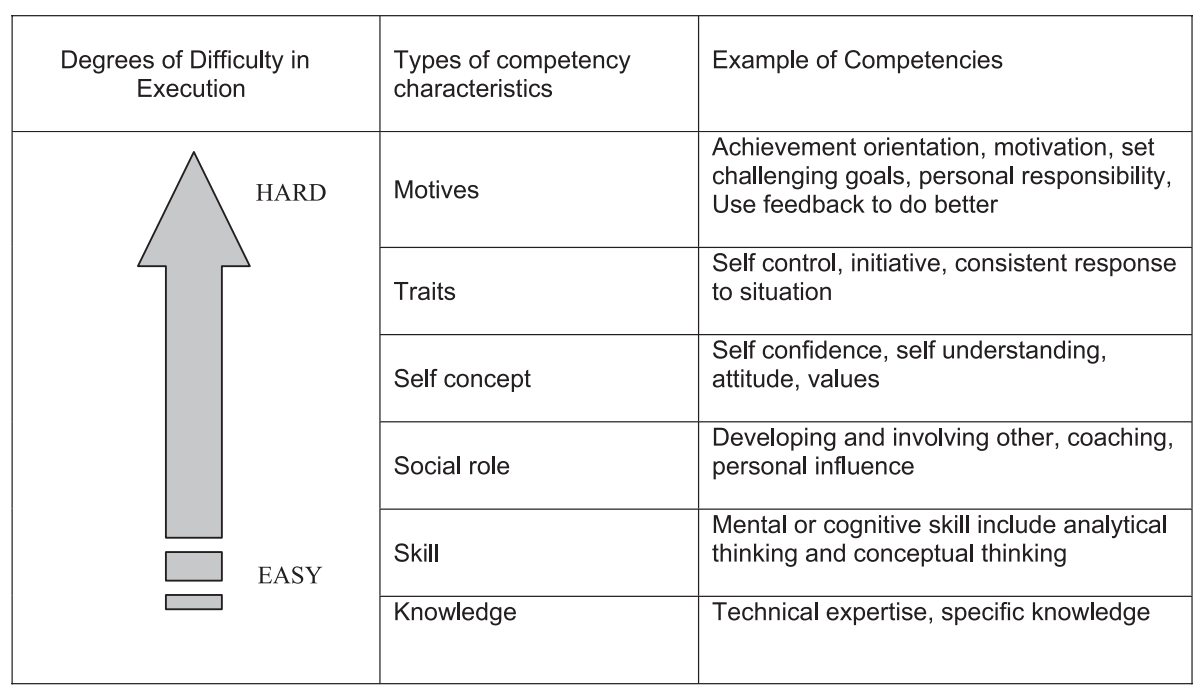

Fig. 1. Degrees of difficulty in execution, types and example of competencies ${ }^{16}$.

also the skills to communicate their expertise to others and the ability to frame the information and strategies employed to gain and retain professional credibility with their various constituencies. The roles and functions of EHS professionals are divided into three clusters of competencies: (1) cognitive competencies which determine what causes a problem and what to do about it; (2) interpersonal competencies that deal with a wide range of stakeholders to gain agreement on the problem and to gain commitment to bring about solutions; and (3) intrapersonal competencies which enable them to be successful ${ }^{12)}$.

\section{Quinn's competency framework for safety manager}

Quinn's competency framework on management ${ }^{20)}$ has been recently adapted for safety managers ${ }^{7)}$. This framework consists of four management models, namely, rational goal, internal process, human relations and open systems model. It also identified eight management roles such as mentor, facilitator, monitor, coordinator, innovator, broker, producer and director. Within this framework, five additional competencies were identified for safety professionals: 1) communicating effectively; 2) accepting responsibility; 3) translating solutions into practical terms; 4) business acumen which refers to the ability to integrate safety into business and to speak the language of business; and 5) the need and ability to provide specific updated measures for safety performance. The additional skills ranked high are technical, good management and interpersonal skills ${ }^{7}$.

\section{Delphi technique as a choice of method}

The Delphi technique consists of four main characteristics $^{21)}$ : a) it is an iterative or repetitive process which requires the experts to be consulted at least twice on the same question; b) it maintains the anonymity of the participants or at least of their answers. c) it takes place in a controlled feedback to reduce noise or information that distorts the data or deals with group interest rather than focusing on problem solving; and d) it allows for group statistical response. All the opinions form part of the final answer. The questions are designed so that the answers can be analyzed statistically.

The validity and reliability of the Delphi technique as an acceptable method of data collection from an identified group has been supported ${ }^{21)}$. The scientific merit of this technique had been proven by the credibility in selection of panel experts, procedures of data gathering, justifiable consensus and explanation on its implementation $^{22,23)}$.

\section{Methods}

\section{The application of the Delphi process}

This study used a modified Delphi technique to identify the competency items for OSH professionals. This modified technique used guided questions in a questionnaire derived from literature reviews for data collection. This is slightly different from the original technique that uses an open ended questionnaire or without guided questions. There were eight steps involved in the data collection procedure:

1. Formation of the review panel to undertake and monitor the Delphi process and selection of panel experts.

2. Communications with the panel of experts by emails, letters and phone calls.

3. Development and testing of Round I, II and III 
and survey questionnaires.

4. Round I: Developing the list of competencies and rating the competencies for preliminary consensus.

5. Analysis and filtration of the responses of Round I

6. Round II: Grouping Round I competencies into categories and ranking the competencies.

7. Round III: Analyzing consensus and developing the competency model

8. Summarizing and preparing the report.

\section{Population and sampling: panel of experts}

The sampling technique used in the identification of the experts was purposive sampling ${ }^{23)}$. A total of 105 invitation letters with an attachment of qualification criteria form were sent to potential participants. Criteria used were background and work experience ${ }^{24)}$. They were OSH practitioners and enforcement officers from various types of organizations in the public and private sectors in Malaysia that were involved in policy and research, industrial safety, industrial hygiene and ergonomics, chemical management, occupational health, offshore and major hazard. The participants were contacted by telephone calls or by emails, and were informed about the study. Thirty six participants responded and expressed their willingness to participate in the study. They submitted their qualification forms via email attachment to the researcher for confirmation. The profile of the panel of experts is given in Table 1 .

The table indicates that the sample was dominated by males (29 or $80.6 \%$ ). For academic qualifications, $15(41.7 \%)$ had a Bachelor degree and $20(55.5 \%)$ had either a Master or a $\mathrm{PhD}$ degree. One member held a diploma with $15 \mathrm{yr}$ of work experience. Based on the work tenure, $17(47.2 \%)$ experts had served for 10 to $15 \mathrm{yr}$, while $19(52.8 \%)$ had worked for more than 15 yr. All the experts were members of various committees related to safety and health and had also shown good performance record in their organizations. Twenty $(58.3 \%)$ of them had presented papers at conferences or seminars in the last five years. They were also professional engineers (5 or $13.9 \%$ ), certified and registered safety and health officers (5 or 13.9\%), and assessors for chemical health risk assessment (3 or $8.3 \%$ ). The rest were officers from the Department of Occupational Safety and Health. The table also indicated that 28 $(77.8 \%)$ of the experts worked in government agencies while $8(22.2 \%)$ worked in private companies.

It has been suggested that at least three separate

Table 1. Demographic profile of expert panel

\begin{tabular}{|c|c|c|c|}
\hline Demographics & Categories & $\begin{array}{l}\text { Frequency } \\
\qquad(\mathrm{n}=36)\end{array}$ & $\begin{array}{c}\text { Percentage } \\
(\%)\end{array}$ \\
\hline \multirow[t]{2}{*}{ Gender } & Male & 29 & 80.6 \\
\hline & Female & 7 & 19.4 \\
\hline \multirow[t]{3}{*}{ Education } & Diploma & 1 & 2.8 \\
\hline & Bachelors & 15 & 41.7 \\
\hline & Master/PhD & 20 & 55.5 \\
\hline \multirow[t]{2}{*}{ Experience } & $10-15 \mathrm{yr}$ & 17 & 47.2 \\
\hline & $16 \mathrm{yr}$ and above & 19 & 52.8 \\
\hline \multirow[t]{3}{*}{ Position } & Director/Deputy Director & 28 & 77.8 \\
\hline & Manager/Senior Manager & 4 & 11.1 \\
\hline & Safety and Health Officer/CHRA Assessor & 4 & 11.1 \\
\hline Committee member & $\begin{array}{l}\text { Part of a safety and health related organization, } \\
\text { and serves on the safety committee of such an } \\
\text { organization. }\end{array}$ & 36 & 100 \\
\hline \multirow{2}{*}{$\begin{array}{l}\text { Presenter in Conference/ } \\
\text { Seminar }\end{array}$} & Yes & 21 & 58.3 \\
\hline & No & 11 & 41.7 \\
\hline \multirow{5}{*}{$\begin{array}{l}\text { License } \\
\text { requirements }\end{array}$} & Professional Engineer (PE) & 5 & 13.9 \\
\hline & Certified Safety and Health Officer (SHO) & 5 & 13.9 \\
\hline & Chemical Health Risk Assessment (CHRA) & 3 & 8.3 \\
\hline & Assessor & & \\
\hline & Others & 23 & 63.9 \\
\hline \multirow[t]{2}{*}{ Good performance record } & Yes & 36 & 100 \\
\hline & No & 0 & 0 \\
\hline \multirow[t]{2}{*}{ Job sector } & Government & 28 & 77.8 \\
\hline & Private & 8 & 22.2 \\
\hline
\end{tabular}


groups of individuals that perform three different roles should participate in a Delphi technique. They were decision makers, individuals who expected some sort of product from the exercise, a group that designed the initial questionnaire, summarized the returns, and redesigned the follow-up questionnaires and finally a group whose judgments were sought and who were asked to respond to the questionnaires ${ }^{25}$. The success of the Delphi technique depends on a combination of participants who make up the panel experts, the size of the panel experts and their qualifications ${ }^{26)}$. In this study, the decision maker was the Director General of DOSH, who acted on behalf of the Ministry of Human Resources, the researcher and a Director of DOSH acted as the review panel, and a group of enforcement officers and OSH practitioners played the role as the expert panel.

\section{Instrument}

The questions in Round I was developed based on several sources such as EHS Competency Model ${ }^{12)}$, Job Analysis for Professionals Safety Practice ${ }^{27)}$, Career Guide to the Safety Profession ${ }^{28)}$, and Quinn's Competency Framework ${ }^{7,16)}$. The expert panel was given the list of competencies needed by OSH professionals and was not required to develop the items as done in the traditional-styled Delphi technique. The list was first pre-tested with three participants for readability, understanding, and clarity of the instructions. As a whole, the results of the pre-test showed that the items developed in the questionnaire were clear and easy to understand.

In Round I, the expert panel was asked to identify the competencies for OSH professionals including cognitive, interpersonal and intrapersonal with threshold and differentiating competencies that represent each area of work functions based on the list of competencies given to them in the questionnaire. Categorization of the competencies as either differentiating or threshold was also done by the expert panel based on the instructions given to them in the questionnaire. The competencies are included in any of the categories when $75 \%$ or more experts agreed on it.

The expert panel then prepared a comprehensive summary. They analyzed if there were any duplicate responses, eliminated redundancy and generated competency items. The items were categorized by differentiating and threshold, and divided into cognitive, interpersonal and intrapersonal categories based on the EHS competency model ${ }^{12}$. They were also free to suggest additional competencies deemed necessary for $\mathrm{OSH}$ professionals.

\section{Data analysis}

As mentioned earlier, a consensus level of $75 \%$ agreement was chosen as the minimum level to accept or reject the list of competency ${ }^{29}$ ). The competencies listed and suggested by the panel were rated according to the level of importance using $0-4$ of a Likert-like scale. The mean and standard deviation were calculated based on the scale of $0=$ Not important, $1=$ Slightly Important, 2=Moderately Important, 3=Important, and $4=$ Critical. It was then decided that a mean of 3.00 or greater suggested that the panel rated the competency item as important. A competency item with a standard deviation of 1.00 or less would indicate that the panel was in consensus on a given competency item rating. Therefore, a competency statement with a mean of 3.00 and above, and standard deviation less than 1.00 were selected for the next questionnaire. The data gathered in this technique were confirmed as a survey research method $^{30)}$. The data were executed in a series of three rounds and systematically controlled; by doing so it enhanced the objectivity and validity of the results obtained $^{23)}$. All the collected data were analyzed (using SPSS version 15.0) and the central tendency measures were used for data description about the study sample.

The Spearman rank correlation coefficient was used between Round I and II to ascertain correlation of Round I and II ranking. In Round III, the binomial test was used to calculate on $75 \%$ agreement on acceptance of the competency items to be included in the competency model for OSH professionals; the number of 'accept' or 'reject' responses was calculated and the binomial test was used to determine whether consensus had actually been achieved at the end of the study ${ }^{24}$. To test the assumption for accept/reject responses, the null hypothesis was that the 'accept' and 'reject' responses are equi-probable. The research hypothesis was that the 'accept' response was more probable than the 'reject' response. Rejecting the null hypothesis would support the research hypothesis that a consensus among the expert panel for the competencies needed for OSH professional has been reached. The result indicated that the 'accept' response were more probable than the 'reject' response at the 0.05 level of significance, therefore the null hypothesis was rejected.

\section{Results}

The results of the Delphi study on the competencies needed for OSH professionals in this study are given in Tables 2 to 6 . In Round III, there were 58 competencies identified as required by OSH professionals. 
Table 2. Round III final generic competencies ordered from highest to lowest by accepted percentage

\begin{tabular}{llllc}
\hline No. Generic competencies & Mean & SD & \% Agreement ${ }^{\mathrm{a}}$ & $\begin{array}{c}\text { Respondents } \\
(\mathrm{n}=32)\end{array}$ \\
\hline 1. Technical expertise & & & & 32 \\
2. Achievement orientation & 3.63 & 0.51 & 100 & 32 \\
3. Communication & 3.33 & 0.65 & 100 & 32 \\
4. Concern of order, accuracy and clarity & 3.32 & 0.73 & 100 & 32 \\
5. Conceptual thinking & 3.26 & 0.51 & 100 & 32 \\
6. Planning & 3.22 & 0.54 & 100 & 32 \\
7. Analytical thinking & 3.21 & 0.50 & 100 & 32 \\
8. Impact and influence & 3.19 & 0.56 & 100 & 32 \\
9. Teamwork and cooperation & 3.17 & 0.68 & 100 & 32 \\
10. Negotiation skills & 3.15 & 0.61 & 100 & 32 \\
11. Management skills & 3.05 & 0.75 & 100 & 32 \\
12. Translation capability & 3.19 & 0.61 & 96.9 & 31 \\
13. Initiative & 3.10 & 0.60 & 96.9 & 31 \\
14. Relationship building & 3.03 & 0.58 & 96.9 & 31 \\
15. Self control & 3.19 & 0.64 & 93.8 & 30 \\
16. Customer service orientation & 3.18 & 0.47 & 93.8 & 30 \\
17. Self confidence & 3.13 & 0.71 & 93.8 & 30 \\
18. Perseverance & 3.11 & 0.65 & 93.8 & 30 \\
19. Involving others & 3.06 & 0.56 & 93.8 & 30 \\
20. Accepting responsibility & 3.04 & 0.57 & 93.8 & 30 \\
21. Perceptual objectivity & 3.17 & 0.64 & 90.6 & 29 \\
22. Information seeking & 3.12 & 0.80 & 90.6 & 29 \\
23. Visioning & 3.09 & 0.50 & 90.6 & 29 \\
24. Business acumen & 3.02 & 0.68 & 90.6 & 29 \\
25. Interpersonal understanding & 3.02 & 0.70 & 87.5 & 28 \\
\hline
\end{tabular}

aThe sequence of items with the same "\% Agreement" is arranged according to descending order of the means.

Table 3. Round III final general knowledge required for OSH professionals

\begin{tabular}{|c|c|c|c|c|c|}
\hline No. & General knowledge required for OSH professionals & Mean & SD & $\%$ Agreement $^{\mathrm{a}}$ & $\begin{array}{l}\text { Respondents } \\
\quad(\mathrm{n}=32)\end{array}$ \\
\hline 1. & Laws, regulations, standards, government & 3.58 & 0.72 & 96.9 & 31 \\
\hline 2. & Training/education & 3.44 & 0.64 & 96.9 & 31 \\
\hline 3. & $\begin{array}{l}\text { Technology (engineering, facilities, equipment, processes, } \\
\text { computers \& systems) }\end{array}$ & 3.36 & 0.77 & 93.8 & 30 \\
\hline 4. & Business and management & 3.19 & 0.71 & 90.6 & 29 \\
\hline 5. & Behavioral and organizational science & 3.14 & 0.69 & 87.5 & 28 \\
\hline 6. & Mathematics, statistics, physical \& chemical sciences & 3.12 & 0.81 & 87.5 & 28 \\
\hline
\end{tabular}

aThe sequence of items with the same "\% Agreement" is arranged in descending order of the means.

\section{Round III generic competencies}

Table 2 depicts 25 generic competencies that included 11 competencies with $100 \%$ agreement (32 members), 3 competencies with $96.9 \%$ agreement (31 members), 6 competencies with $93.8 \%$ agreement (30 members), 4 with $90.6 \%$ agreement (29 members) and lastly 1 competency with $87.5 \%$ agreement ( 28 members).

\section{Round III general knowledge}

The Round III survey questionnaire was designed to have the expert panel agreement on accepting the competency items to be included in the competency framework for OSH professionals. Six general competencies were accepted by the expert panel (Table 3). There was $96.9 \%$ (31 members) agreement for two items, 93.8\% (30 members) agreement for 1 item with, 90.6\% (29 members) agreement for another item and lastly 
Table 4. Round III final specific safety and health knowledge required for OSH professionals

\begin{tabular}{lcccc}
\hline No. Specific safety and health knowledge for OSH professionals & Mean & SD & \% Agreement ${ }^{\mathrm{a}}$ & $\begin{array}{c}\text { Respondents } \\
(\mathrm{n}=32)\end{array}$ \\
\hline 1. Inspections, investigations, audits & 3.55 & 0.59 & 100 & 32 \\
2. OSH in design, controls, technology & 3.35 & 0.68 & 100 & 32 \\
3. Industrial hygiene & 3.33 & 0.63 & 100 & 32 \\
4. Safety management & 3.19 & 0.60 & 100 & 32 \\
5. Ergonomics & 3.17 & 0.55 & 100 & 32 \\
6. Emergencies & 3.25 & 0.60 & 96.9 & 31 \\
7. Applied OSH-Construction & 3.25 & 0.60 & 96.9 & 31 \\
8. Professional development and ethics & 3.03 & 0.73 & 96.9 & 31 \\
9. General knowledge on safety and health sciences and issues & 3.38 & 0.69 & 93.8 & 30 \\
10. Applied OSH-Systems & 3.33 & 0.63 & 93.8 & 30 \\
11. Applied OSH-Process/Petrochemical & 3.23 & 0.50 & 93.8 & 30 \\
12. Environmental & 3.08 & 0.72 & 93.8 & 30 \\
13. Applied OSH-Occupational health & 3.08 & 0.65 & 87.5 & 28 \\
14. Fire protection & 3.42 & 0.50 & 84.4 & 27 \\
15. Risk management \& insurance & 3.25 & 0.83 & 81.3 & 26 \\
\hline
\end{tabular}

aThe sequence of items with the same "\% Agreement" is arranged in descending order of the means.

Table 5. Round III final skills required for OSH professionals

\begin{tabular}{lcccc}
\hline No. Skills required for OSH professionals & Mean & SD & \% Agreement ${ }^{\mathrm{a}}$ & $\begin{array}{c}\text { Respondents } \\
\text { (n=32) }\end{array}$ \\
\hline 1. Inspection and investigative skills & 3.38 & 0.60 & 100 & 32 \\
2. Applied safety and health skills & 3.28 & 0.76 & 100 & 32 \\
3. General and applied verbal communication skills & 3.24 & 0.73 & 100 & 32 \\
4. General and applied written communication skills & 3.18 & 0.81 & 100 & 32 \\
5. General and applied human behaviors skills & 3.16 & 0.68 & 100 & 32 \\
6. General and applied mathematical, analytical and scientific skills & 3.21 & 0.76 & 96.9 & 31 \\
7. General and applied business, organization and leadership skills & 3.25 & 0.71 & 93.8 & 30 \\
8. General and applied training skills & 3.14 & 0.71 & 93.8 & 30 \\
9. Ethics application skills & 3.33 & 0.76 & 90.6 & 29 \\
10. General and applied interpreting skills & 3.28 & 0.76 & 90.6 & 29 \\
11. Creative skills & 3.21 & 0.77 & 90.6 & 29 \\
12. General and applied computer and system skills & 3.28 & 0.80 & 87.5 & 28 \\
\hline
\end{tabular}

aThe sequence of items with the same "\% Agreement" is arranged in descending order of the means.

$87.5 \%$ agreement (28 members) for 2 items.

\section{Round III specific knowledge}

The data showed that 15 specific competencies were accepted by the panel experts to be included in the competency framework for OSH professionals (Table 4). Five items were agreed with $100 \%(32$ members), 3 items with $96.9 \%$ agreement (31 members), 4 items with $93.8 \%$ (30 members), 1 item with $87.5 \%$ (28 members), 1 item with $84.4 \%$ (27 members) agreement and lastly 1 item with $81.3 \%$ agreement (26 members).

\section{Round III skills}

Table 5 shows the data of 12 skills/competencies that were accepted by the panel of experts to be included in the competency framework for OSH professionals. Five items were agreed with $100 \%$ (32 members), 1 item with $96.9 \%$ agreement ( 31 members), 2 items with 93.8\% (30 members), 3 items with $90.6 \%$ (29 members) and lastly 1 item with $87.5 \%$ agreement (28 members).

\section{Competency framework for OSH professionals}

Based on the overall results from Round I to Round III, a competency framework for OSH professionals was generated. This competency framework consists of clusters of competency such as cognitive, interpersonal and intrapersonal and also category of competencies such as threshold and differentiating competencies. Table 6 shows the competency items and the categories. 


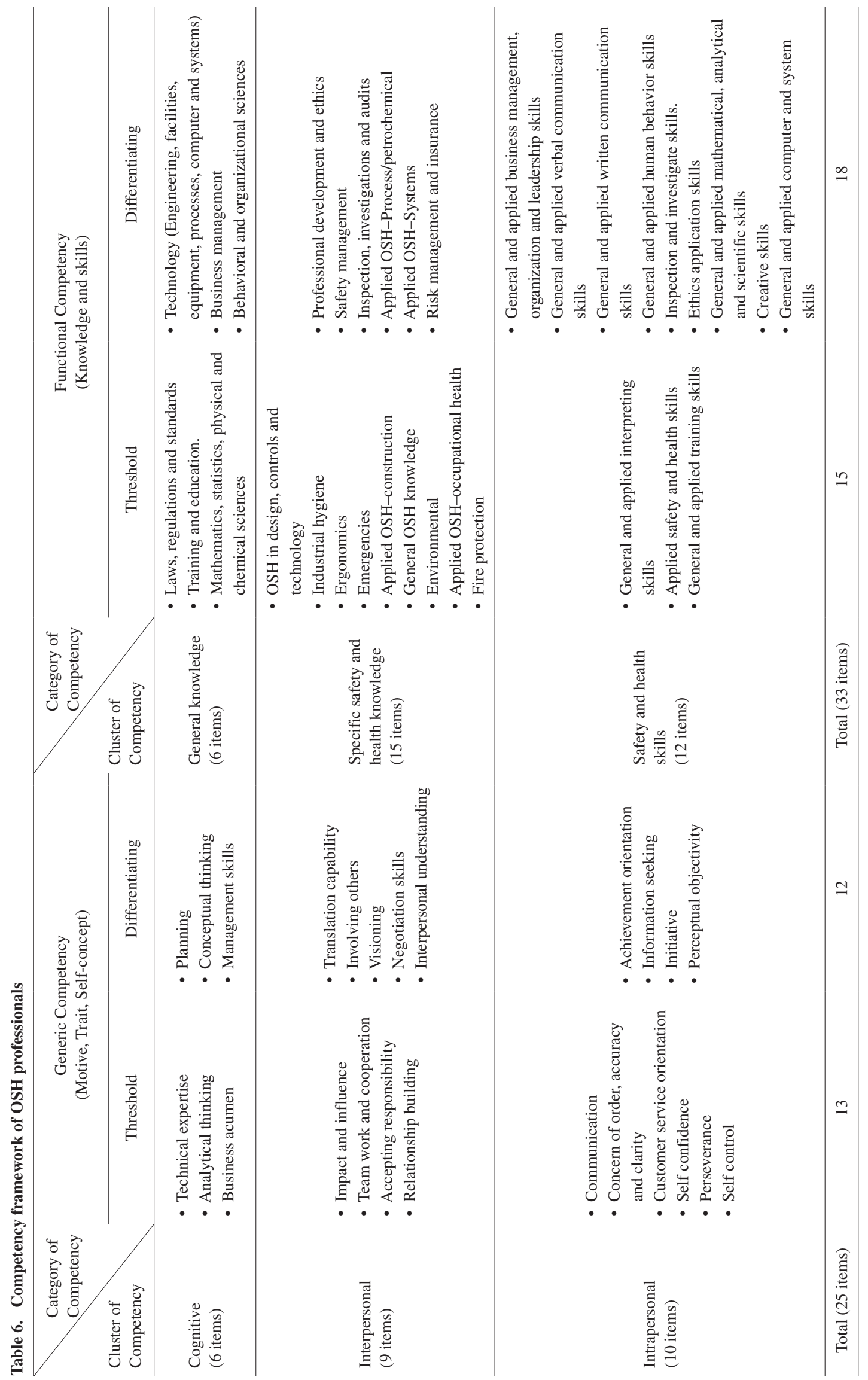


Generic competencies which consist of motive, trait and self concept is made up of 13 threshold and 12 differentiating competencies. According to competency cluster, 3 items were in cognitive competency, 4 items interpersonal competency and 6 items intrapersonal competency. Meanwhile, for specific or functional competencies which include knowledge and skills, there were 15 threshold and 18 differentiating competencies.

\section{Discussion, conclusion, and implications}

This study has identified 25 generic competencies and 33 specific or functional competencies for $\mathrm{OSH}$ professionals. The 25 generic competencies consist of 13 threshold and 12 differentiating competencies while specific or functional competencies consist of 15 threshold and 18 differentiating competencies. It is important to note that the initial competency items included were 27 generic competencies and 21 specific competencies which were listed based on EHS competencies ${ }^{12)}$ and critical competencies for safety managers ${ }^{7)}$. The safety degree curriculum ${ }^{27)}$ and the Career Guide by the American Society of Safety Engineers Foundation (ASSE) and the Board of Certified Safety Professionals $(\mathrm{BCSP})^{28)}$ were also used in Rounds II and III by the expert panel to rate competencies from Round II into outcome categories as well to rank them in Round III. The competencies were grouped into three categories; cognitive, interpersonal and intrapersonal competencies with their rate of importance being further categorized into threshold and differentiating competencies.

From the 27 generic competencies in the initial list of competency items, 2 cognitive competency items were not accepted as necessary since their means were less than 3.0. The two competencies are 'Knowledge of business, accounting and marketing' and 'Economic analysis and risk assessment' with 75\% (27) and 80.6\% (29) agreement respectively. A reason for this result could be due to the composition of the sample in which 28 members $(77.8 \%$ of expert panel) were from public sector that were more concerned about delivery of services rather than profit-making.

The competency framework that consists of 13 threshold competencies included technical expertise, analytical thinking, business acumen (cognitive competency), impact and influence, teamwork and cooperation, accepting responsibility and relationship building (interpersonal competency) and communication, concern of order, accuracy and clarity, customer service orientation, self confidence, perseverance and self control (intrapersonal). Meanwhile, differentiating competencies included planning, conceptual thinking and management skills (cognitive competency), translation capability, involving others, visioning, negotiation skills and inter- personal understanding (interpersonal competency) and achievement orientation, information seeking, initiative and perceptual objectivity (intrapersonal competency).

Functional competencies consist of 15 thresholds such as laws, regulations and standard; mathematics, statistics, physical and chemicals sciences, and training and education, and 18 differentiating competencies such as technology, human behavioral sciences, risk management and insurance, safety management and inspections, investigations and audits.

Technical expertise had the highest range of importance in the generic competency. Although it has the highest mean score, it is found in the threshold competencies. These findings are supported ${ }^{11)}$ as these competencies were required for minimal performance. This is followed by analytical thinking that was important in technical jobs for the OSH professionals in anticipating and planning for obstacles, seeing the implications or consequences of situations, and making logical conclusions. The results support findings from most of the previous studies ${ }^{7,11,13)}$. This study shows that technical expertise, analytical thinking and communication were most important as a basis for the work of OSH professionals and these results suggest the importance of managerial competencies that were included in the generic competencies.

It can also be concluded that Round I to III of the Delphi study was able to generate competencies needed for $\mathrm{OSH}$ professionals to perform excellently, in terms of differentiating and threshold competencies. Therefore, the use of the Delphi technique as a study method has been expanded to the $\mathrm{OSH}$ profession in a Malaysian context. The relationship between this competency framework generated and the models used in the study is summarized in Table 7. The summary clearly shows that the competencies derived from the study are in congruence with the models used and that the three models, Iceberg Competency Model ${ }^{16)}$, Quinn's Competency Framework ${ }^{20)}$ and ESH Competency Model $^{12)}$, were able to help in exploring competencies needed by OSH professionals in this study.

These results can be used as a basis to prepare for university curricular in Malaysia for the relevant OSH professions. Meanwhile, industrial organizations can use these OSH competencies for their induction and on-the-job training program. Future studies are suggested to incorporate emerging issues, such as competencies needed by Malaysian OSH professionals for global assignments and vice versa for expatriates. Competencies needed from gender perspectives are also worth exploring since there are increased numbers of women going into engineering and safety-based employment. Similarly, comparative OSH studies in public- 
Table 7. Summary of competency framework and the models used in the study

\begin{tabular}{|c|c|c|c|c|c|}
\hline \multirow{2}{*}{$\begin{array}{l}\text { Iceberg Competency Model } \\
\text { (Spencer and Spencer, } \\
\text { 1993); Quinn's Competency } \\
\text { Framework (Blair, 2004) }\end{array}$} & \multirow{2}{*}{$\begin{array}{l}\text { EHS Competency Model } \\
\text { (Leemann, 2005); Quinn's } \\
\text { Competency Framework (Blair, } \\
\text { 2004) }\end{array}$} & \multicolumn{4}{|c|}{$\begin{array}{l}\text { OSH Professional Competency Framework } \\
\text { (from study) }\end{array}$} \\
\hline & & \multicolumn{2}{|l|}{ Generic } & \multicolumn{2}{|l|}{ Functional/Specific } \\
\hline \multirow{4}{*}{$\begin{array}{c}\text { Skill } \\
\text { Knowledge } \\
\text { (Visible) }\end{array}$} & \multirow{4}{*}{$\begin{array}{l}\text { Threshold competencies - } \\
\text { essential characteristics that } \\
\text { everyone in a job must possess } \\
\text { in order to perform the job at } \\
\text { minimally effective level. } \\
\text { (Including cognitive, } \\
\text { interpersonal and intrapersonal } \\
\text { competencies) }\end{array}$} & Cognitive & 3 & General Knowledge & 3 \\
\hline & & Interpersonal & 4 & $\begin{array}{l}\text { Specific safety and health } \\
\text { knowledge }\end{array}$ & 9 \\
\hline & & Intrapersonal & 6 & the & 3 \\
\hline & & $\begin{array}{l}\text { Total generic threshold } \\
\text { competencies }\end{array}$ & (13) & $\begin{array}{l}\text { Total functional threshold } \\
\text { competencies }\end{array}$ & (15) \\
\hline \multirow{5}{*}{$\begin{array}{l}\text { Self-concept } \\
\text { Trait } \\
\text { Motive } \\
\text { (Hidden) }\end{array}$} & \multirow{5}{*}{$\begin{array}{l}\text { Differentiating competencies - } \\
\text { the characteristics (motive, trait } \\
\text { and or pattern of behavior) that } \\
\text { distinguish superior from aver- } \\
\text { age performers. } \\
\text { (Including cognitive, } \\
\text { interpersonal and intrapersonal } \\
\text { competencies) }\end{array}$} & Cognitive & 3 & General Knowledge & 3 \\
\hline & & Interpersonal & 5 & $\begin{array}{l}\text { Specific safety and health } \\
\text { knowledge }\end{array}$ & 6 \\
\hline & & Intrapersonal & 4 & & \\
\hline & & & & Skills & 9 \\
\hline & & $\begin{array}{l}\text { Total generic differentiating } \\
\text { competencies }\end{array}$ & (12) & $\begin{array}{l}\text { Total functional differentiating } \\
\text { competencies }\end{array}$ & (18) \\
\hline \multicolumn{2}{|c|}{ Total } & \multicolumn{2}{|l|}{25} & \multicolumn{2}{|l|}{33} \\
\hline
\end{tabular}

engineering organizations and multi-national corporations, and the learning strategies needed for the different types of competencies are other possible research areas in the future.

\section{References}

1) Manuaba A (2006) Total approach is a must for small and medium enterprises to attain sustainable working conditions and environment, with special reference to Bali, Indonesia. Ind Health 44, 22-6.

2) Araki S, Tachi M (2003) National occupational health research priorities, agenda and strategy of Japan: invited report in NORA Symposium 2001, USA. Ind Health 40, 49-54.

3) Park H, Ha E, Kim J, Jung H, Paek D (2002). Occupational health services for small-scale enterprises in Korea. Ind Health 40, 1-6.

4) WHO/ILO (2006) Malaysia Country Report. 1-9. http:// www.wpro.who.int/NR/rdonlyres/.../0/MAAcountryprofile. pdf. Accessed May 20, 2009.

5) Hashim SB, Amin FB, Khalid HM (2005) Malaysia Country Report. WHO/ILO Meeting on Strengthening Occupational Safety and Health, Kuala Lumpur.

6) Henshaw JL (2007) Career guide to the safety profession. American Society of Safety Engineers Foundation and the Board of Certified Safety Professionals, United State.

7) Blair EH (2004) Critical competencies for SH\&E managers: implications for educators. J SH\&E Research 1, $1-16$.

8) Occupational Safety and Health Act (OSHA) (1994)
Percetakan Nasional Berhad, Kuala Lumpur.

9) DOSH (2009) Amalan budaya kerja selamat (Safe practices work culture). www.dosh.gov.my/doc/dosh. pdf. Accessed May 2, 2009.

10) MBAM - Master Builders Association Malaysia (2005) Industry needs more safety and health officers. http:// www.mbam.org.my/mbam/index.php?...\&task=view\&id =584\&Itemid=331. Accessed April 10, 2009 .

11) Government of Malaysia (2006) Ninth Malaysia Plan 2006-2010. Prime Minister's Department, Putrajaya.

12) Leemann JE (2005) Delivering business value by linking behavioral EHS competencies to corporate core competencies. Int J Sustainable Business 12, 3-16.

13) Halim A (2003) Training needs assessment of safety and health officers in the state of Selangor. NIOSH Research Project, Bangi, Selangor.

14) Sabri $Z$ (2006) The sufficiency of current training curriculum for different industries and adequacy of the minimum academic requirement for safety and health officer. Master of Science in Construction Management Dissertation, University Technology of Malaysia.

15) Boyatzis RE (1982) The competent manager: a model for effective performance. John Wiley \& Sons, New York.

16) Spencer LM Jr, Spencer SM (1993) Competence at work: models for superior performance. Wiley, New York.

17) Adams SJ (2003) The emerging management school of safety: SH\&E professionals must develop business skills to succeed. Professional Safety 48, 18-21.

18) Kogi K (2002) Work improvement and occupational safety and health management systems: common fea- 
tures and research needs. Ind Health 40, 121-33.

19) Mori K, Takebayashi $T$ (2002) The introduction of an occupational health management system for solving issues in occupational health activities in Japan. Ind Health 40, 167-74.

20) Quinn RE, Faerman SR, Thompson MP, McGrath MR (1996) Becoming a master manager: a competency framework. Wiley, New York.

21) Helmer O (1983) Looking forward: a guide to future research. Sage, Beverly Hills.

22) Thangaratinam S, Charles WE (2005) The Delphi technique. The Obstetrician \& Gynecologist 7, 120-5.

23) du Plessis E, Human SP (2007) The art of the Delphi technique: highlighting its scientific merit. Health SA Gesondheid. http://www.thefreelibrary.com/_/print/ PrintArticle.aspx?id=173465242. Accessed May 14, 2009.

24) Armstrong AE (2000) An inquiry into moral virtues, especially compassion, in psychiatric nurses: findings from a Delphi study. J Psychiatr Ment Health Nurs 7,
297-306.

25) Delbecq AL, Van de Ven AH, Gustafson DH (1975) Group techniques for program planning. Scott Foresman and Co, Glenview.

26) Powel C (2003) The Delphi technique. Myths and realities. J Adv Nurs 19, 1221-5.

27) Brauer RL (2005) Evaluating a safety degree curriculum using job analysis for professional safety practice. J SH\&E Research 2, 1-35.

28) ASSE and BCSP (2007) Career guide to safety profession. American Society of Safety Engineers Foundation and the Board of Certified Safety Professionals, 3rd Ed., Des Plaines.

29) Edgren G (2006) Developing a competence-based core curriculum in biomedical laboratory science: a Delphi study. Med Teach 28, 409-17.

30) Cohen MZ, Harle M, Woll AM, Despa S, Munsell MF (2004) Delphi survey nursing research priorities. Oncol Nurs Forum 31, 1011-8. 